\title{
A SURVEY OF SOIL FERTILITY STATUS OF FOUR AGROECOLOGICAL ZONES OF MOZAMBIQUE
}

\author{
Ricardo M. Maria and Russell Yost
}

\begin{abstract}
Mozambique includes 10 agroecological zones with distinct climate and cropping systems (INIA, 1980). Agricultural production is more intensively practiced in the central and northern parts of the country where agroecological conditions are favorable. As a result of 16 years of civil war and low funding for agricultural research few assessments of soil nutrient status have been possible. To assess soil nutrient status, four agriculturally promising agroecological zones were selected for a survey. Sixty-two sites were sampled, and composite samples of surface and subsurface soils were taken and analyzed for properties considered critical for the production of food crops. The sample points were recorded with a differential global position system and mapped. The results indicate that most of the soils are low in effective cation exchange capacity, moderate in organic matter, moderate to strongly acidic, moderately weathered, and moderate to high in $\mathrm{P}$ sorption capacity. In general, these soils can be classified as having low to moderate fertility. Findings of this study indicate limitations of the existing map of soil resources of Mozambique. The results of this study suggest that additional sampling and soil survey will be required to improve the quality of soil surveys for site-specific applications. A site-specific soil survey is recommended that would provide additional information on soil resources and would greatly improve the current soil map that has an inadequate soil database. Furthermore, calibration and correlation studies are recommended for better decisions on soil nutrient management for ensuring food security. (Soil Science 2006;171:902-914)
\end{abstract}

Key words: Nutrient management, maize, cotton, sorghum, $P$, soil mapping.

$\mathbf{M}$ OZAMBIQUE, recently announced as one of the Millenium Challenge countries of Africa, is only recently recovering from 16 years of a devastating civil war and resulting famine. The agricultural sector contributes up to $25 \%$ of the gross domestic product and $65 \%$ of the total value of exports. Nevertheless, little information is currently available for farmers and extension workers to use in making informed decisions on soil and nutrient management to improve selection and crop production. Field surveys have consistently indicated that low soil fertility is a limiting factor. Folmer et al., (1998) attempted

Instituto de Investigação Agrária de Moçambique and University of Hawaii at Manoa. Dr. Yost is corresponding author. E-mail: rsyost@hawaii.edu

Received Oct. 11, 2005; accepted May 23, 2006

DOI: $10.1097 / 01 . s s .0000228058 .38581$. de to predict zones of potential nutrient problems with a mathematical model based on land units and land use systems. Although his study indicates which areas are likely to have soil fertility problems, it does not provide information for estimating plant nutrient requirements nor does it provide site-specific recommendations.

A survey of soil fertility status, which includes soil sampling and analysis, would provide valuable information for diagnosis and prediction of fertilization needs. The objective of this study was to begin such an inventory and assessment of soil nutrient status, which could lead to effective site-specific soil nutrient management and better use of soil resources and increased food security. The result of this survey could also be the beginning of calibration and correlation studies for specific agroecological zones of Mozambique. 


\section{MATERIAL AND METHODS}

\section{Main Features of Study Locations}

Ten agroecological zones (AEZ) of Mozambique have been identified, based on climate, soil type, elevation, and farming system. Four of these zones represent vast areas, covering one or more Food and Agriculture Organization (FAO) soil units. A summary description of each of the AEZ $(\mathrm{R})$ is given as follows:

\section{High Elevation, Inland Manica Province (R10)}

The R10 region is high elevation, situated $1000 \mathrm{~m}$ above sea level. The mean annual rainfall exceeds $1200 \mathrm{~mm}$. The mean annual temperature is between 15 and 22 degrees. The predominant soils are probably Ultisols of high clay content. The main crops are maize, sorghum, millet, and finger millet.

\section{Medium Elevation Manica Province (R4)}

The R4 region includes land between 200 and $1000 \mathrm{~m}$ above sea level. The annual rainfall ranges from 1000 to $1200 \mathrm{~mm}$. The main food crops are maize, sorghum, and millet. There is a high potential for cotton production in this region. The predominant soil type is probably Oxisols with low fertility. The risk of soil erosion in some areas is very high because of topography of the terrain.

\section{Coastal Littoral of Nampula (R8)}

In this region, the average temperature is higher than $25{ }^{\circ} \mathrm{C}$. The range of annual rainfall is between 800 and $1200 \mathrm{~mm}$, and the evapotranspiration is more than $1400 \mathrm{~mm}$. The predominant soil type in this agroecological region is Alfisols. Cotton is the main cash crop cultivated by small-scale sector and joint venture companies. Other crops cultivated in great extent are maize, sorghum, millet, and cassava.

\section{Inland of Nampula and Cabo Delgado (R7)}

The AEZ 7 is a vast region in the northern Mozambique. The elevation ranges from 200 to $1000 \mathrm{~m}$ above sea level. The annual rainfall ranges from 1000 to $1400 \mathrm{~mm}$. There is variability in soil type. The most predominant soils are probably Ultisols and Oxisols. There is a problem of soil acidity in this region, especially in the plateau region.

Most of the crops cultivated are maize, cassava, groundnut, and beans. Cotton is the most important cash crop and is cultivated both by small-scale farmers and joint venture cotton production companies.

\section{Selection of Soil Sample Locations}

The soil sampling plan covered four agroecological regions, two in northern Mozambique (R7 and R8), and two in the central provinces of the country (R4 and R10) (Fig. 1). Criteria for selecting those regions were (i) high potential for food production, (ii) existence of potential users, (iii) presence of excellent agricultural support services, and (iv) high accessibility by roads. In the absence of a detailed soil classification map, the selection of sites for soil sampling in each location was conducted based on district extension workers' knowledge of existing agricultural potential and the approximate distribution of soils in the area. Soil samples were taken from unfertilized agricultural land following an approximately random pattern. At each of the 64 sites, three subsamples were composited from the depths of 0 to $15 \mathrm{~cm}$ and 15 to $30 \mathrm{~cm}$ using a soil auger. The sample locations were recorded using a differential global position system unit Trimble GeoExplorer 3, Sunnyvale, CA.

\section{Laboratory Analysis}

\section{Soil Analysis}

Soil samples were analyzed for color, particle size, $\mathrm{pH}$, and effective cation exchange capacity (ECEC). The soil air-dry color was determined with Munsell soil color chart outside of the laboratory during the noon hours, and the particle size was determined by the pipette method after destruction of the organic matter $(\mathrm{OM})$ with hydrogen peroxide and dispersion with sodium hexametaphosphate (Gee and Bauder, 1986). The $\mathrm{pH}$ was measured with a glass electrode in a 1:1 soil-water suspension and in a 1:1 soil-1 $M \mathrm{KCl}$ suspension. The electrical conductivity was determined in a 1:2.5 soil-water suspension. The exchangeable bases ( $\mathrm{Na}, \mathrm{Ca}$, and $\mathrm{Mg}$ ) and $\mathrm{Al}$ were extracted with $1 \mathrm{M} \mathrm{KCl}$ in a 1:50 ratio in duplicate and determined with an atomic absorption spectrophotometer. Potassium, P, and micronutrients ( $\mathrm{Fe}, \mathrm{Mn}, \mathrm{Zn}, \mathrm{Cu}$, and $\mathrm{B}$ ) were extracted with the Mehlich 3 extractant using a 1:10 soil-solution ratio and determined with inductively coupled plasma spectrophotometer. The ECEC was computed as the sum of KCl-exchangeable $\mathrm{Al}$ and bases. The percentage of Al saturation was calculated in relation to ECEC. The total carbon and nitrogen were determined by combustion with LECO CN 2000 automatic analyzer (LECO Corp., St. Joseph, MI). 


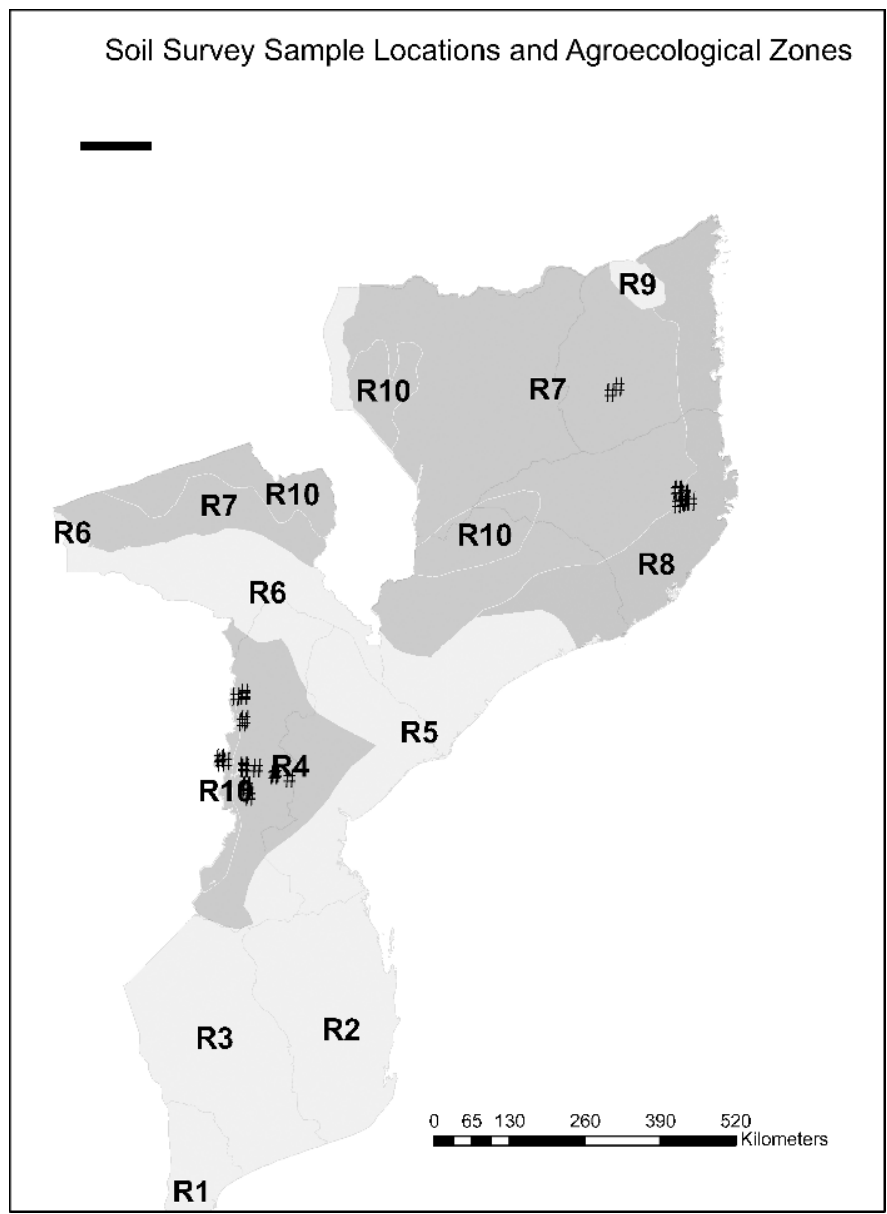

Fig. 1. Sample locations in northern and central Mozambique and AEZ.

\section{Soil Mineralogy}

The clay minerals were determined with X-ray diffraction methods (Moore et al., 1989). The air-dried soil was ground to pass a $2-\mathrm{mm}$ sieve, put in $50-\mathrm{mL}$ centrifuge tube with approximately $30 \mathrm{~mL}$ of water, and centrifuged at $13,500 \mathrm{~g}$ to remove soluble salts. The supernatant was discarded. The operation was repeated twice. The clay fraction was obtained by centrifuging at approximately $75.5 \mathrm{~g}$, and the supernatant liquid decanted to a separate tube, which was centrifuged at 30,215 g. This operation was repeated until enough clay was obtained for analysis. The concentrated fine clay was placed in a glass slide and dried at room temperature for $24 \mathrm{~h}$. X-ray diffraction was conducted with Siemens D-500 and Scintag PAD V automated diffractometer, at $0.0320^{\circ}$ $\left(20^{\circ}\right) / \mathrm{min}$ with $\mathrm{Cu} \mathrm{K} \alpha$ radiation.

\section{P Sorption Curves}

$\mathrm{P}$ sorption was determined by the Fox and Kamprath (1970) procedure. Three grams of airdried soil that passed a $2-\mathrm{mm}$ sieve were equilibrated in $50-\mathrm{mL}$ plastic centrifuge tubes with $30-\mathrm{mL} \mathrm{KH}_{2} \mathrm{PO}_{4}$ solution containing $0,2.5,5,10$, and $20 \mathrm{mg} \mathrm{P}$ per liter for 6 days. An electrolyte concentration of $0.01 \mathrm{M} \mathrm{CaCl}_{2}$ was selected to represent the soil solution environment of tropical soils with low ion exchange capacity (Rajan and Fox, 1972). Two drops of toluene was added in each sample. Each P level was conducted in duplicate. The samples were shaken horizontally in a reciprocal shaker for a 30-min period twice daily for 6 days and centrifuged at 30,215 g for 10 min and filtered. $\mathrm{P}$ in the supernatant solution was determined with the ammonium molybdophosphate-complex method (Olsen and Sommers, 1982). The $\mathrm{P}$ remaining in the solution was 


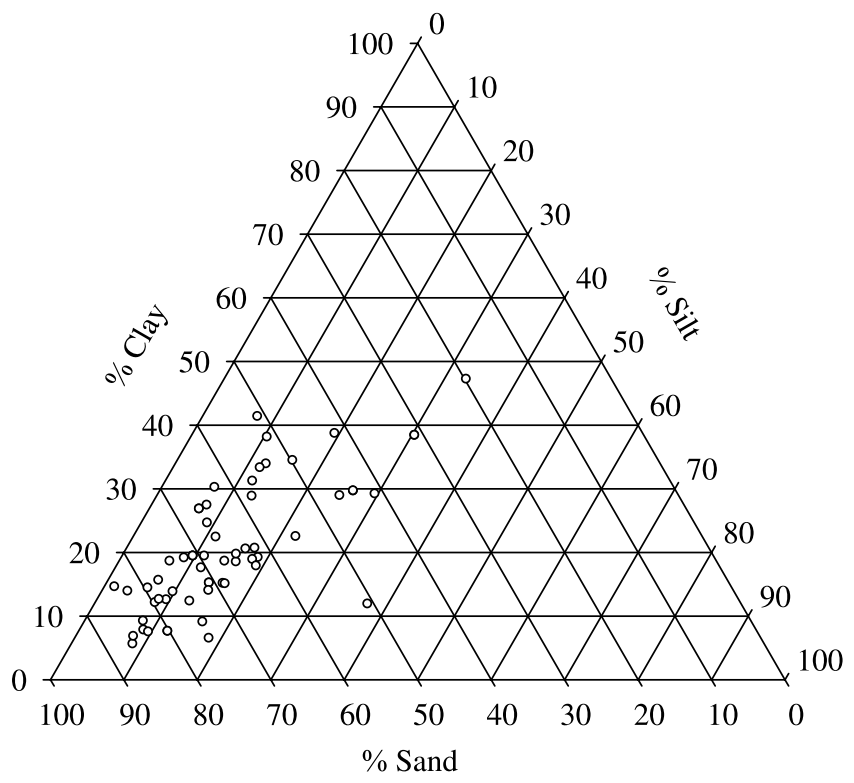

Fig. 2. Particle size distribution of selected Mozambique topsoils $(0-15 \mathrm{~cm})$.

plotted against $\mathrm{P}$ sorbed, and a comparison of $\mathrm{P}$ sorption capacity was conducted by interpolating the amount of $\mathrm{P}$ needed to obtain $0.2 \mathrm{mg}$ $\mathrm{L}^{-1}$ in the soil solution. Grouping of soils was made according to the intervals proposed by Juo and Fox (1977).

\section{Statistical Analyses}

Several statistical analyses were performed using various procedures provided by the Statistical Analysis Systems computer package (SAS Institute, 1997). Comparisons among soils were made with analysis of variance using the general linear model procedure.

\section{RESULTS AND DISCUSSION}

Particle Size Distribution and Mineralogy

Soil texture analysis indicates that most of the soils fall in the loamy sand, sandy loam, and sandy clay loam classes. The median of sand, silt, and clay fractions was $67 \%, 12.1 \%$, and $19.2 \%$, respectively. The clay content ranged from $2.8 \%$ to $47.3 \%$ (Fig. 2, Table 1). Only 2 samples contained $40 \%$ or more clay, and $17 \%$ of the samples contained less than $10 \%$ clay. The silt/ clay ratio of topsoil was relatively high. Roughly $56 \%$ of the samples had a silt/clay ratio greater than 0.5 , and only 2 samples had a ratio less than 0.12 . Silt/clay ratio greater than 0.12 has been used as an indicator of less weathered soils (Ribeiro, 1976). Overall, the topsoil has lower clay content than subsurface layers, which suggests clay eluviation (Whittig, 1959).

$\mathrm{X}$-ray analysis indicated some differences and similarities in the types of clay (Fig. 3). Most of the soils exhibited a high reflection intensity from spacing near 7.2 and 3.6 $\AA$, which corresponds to kaolinite (Brindley and Brown, 1980). The samples showed some smectitic properties such as shrink and swell with wetting. However, the intensity of the peak in the range 16.9 to $19.1 \AA$ was weak

TABLE 1

Means of soil properties of four agriculturally important agroecological zones of Mozambique, 2004 sampling

\begin{tabular}{|c|c|c|c|c|c|c|c|c|c|c|c|c|}
\hline \multirow{3}{*}{ AEZ } & \multicolumn{9}{|c|}{ Chemical properties } & \multicolumn{3}{|c|}{ Particle size } \\
\hline & $\mathrm{pH}$ & ECEC & $\mathrm{Ca}$ & $\mathrm{Mg}$ & $\mathrm{K}$ & $\mathrm{Na}$ & $\mathrm{Al}$ & $\mathrm{Fe}$ & $\mathrm{Mn}$ & Sand & Silt & Clay \\
\hline & \multicolumn{7}{|c|}{$\ldots \ldots \ldots \ldots \ldots \ldots \mathrm{cmol}_{\mathrm{c}} \mathrm{kg}^{-1} \ldots \ldots \ldots \ldots$} & \multicolumn{2}{|c|}{$--\mathrm{mgkg}^{-1}--$} & \multicolumn{3}{|c|}{$-\ldots \%-\ldots$} \\
\hline 10 & 5.5 & 2.38 & 2.33 & 0.68 & 0.38 & 0.41 & 0.25 & 0.29 & 0.74 & 68.8 & 1.1 & 15.1 \\
\hline 4 & 5.8 & 3.88 & 3.50 & 0.78 & 0.45 & 0.42 & 0.38 & 0.48 & 0.71 & 65.7 & 0.9 & 19.9 \\
\hline 7 & 6.0 & 4.83 & 4.16 & 1.39 & 0.35 & 0.42 & 0.18 & 0.46 & 0.94 & 64.8 & 0.6 & 23.3 \\
\hline 8 & 6.3 & 5.38 & 4.34 & 1.23 & 0.67 & 0.51 & 0.28 & 0.40 & 0.84 & 66.1 & 1.1 & 18.7 \\
\hline
\end{tabular}



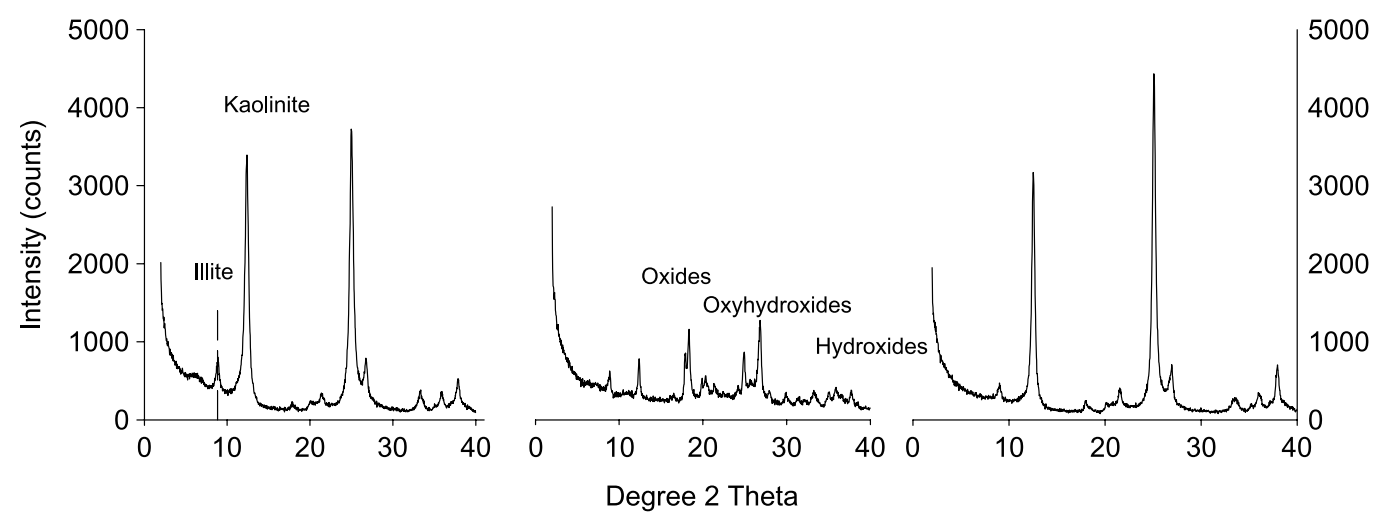

Fig. 3. X-ray diffractograms of surface soils $(0-15 \mathrm{~cm})$. Note: symbols in the figure indicate K-kaolinite and I-Illite.

(Fig. 3). The common accessory minerals in most of the soils were hydroxides, oxyhydroxides, and oxides of $\mathrm{Fe}$ and $\mathrm{Al}$. There is evidence of hematite$\alpha-\mathrm{Fe}_{2} \mathrm{O}_{3}$ (red color) goethite- $\alpha-\mathrm{FeOOH}$ (yellow brown) and gibbsite- $\mathrm{Al}(\mathrm{OH})_{3}$, which correspond to reflection intensities in the regions 2.3 to $2.5 \AA$, 4.1 to $4.9 \AA$, and 4.7 to $4.85 \AA$, respectively. Traces of illite appeared in some samples (Fig. 3 ). There was a consistent weak peak near $10 \AA$ in the soil from Manica (AEZ 4).

\section{Soil Acidity}

The $\mathrm{pH}$ in water varied considerably among sample sites. The range was from 4.4 to 7.8 (Fig. 4). The median was 6.0, the S.D. was 0.53, and the coefficient of variation was 8.9 . Considering a soil $\mathrm{pH}$ between 5.0 and 5.5 as strongly acidic and below 5.0 extremely acidic, $12.9 \%$ of the samples were in the "strongly" and "extremely acidic" categories. These soils are likely to cause $\mathrm{Al}$ and $\mathrm{Mn}$ toxicity or $\mathrm{Ca}$ and $\mathrm{Mg}$ deficiency if planted to acid sensitive species such as cotton and certain varieties of sorghum and soybean. Approximately $76 \%$ of the samples were within adequate levels of $\mathrm{pH}(5.5-6.5)$, and $11.3 \%$ of the samples have pH greater than 6.5 and less than 7.8 (Fig. 4). The soils with a high $\mathrm{pH}$ are likely to have micronutrient deficiencies in $\mathrm{Zn}$ and $\mathrm{Fe}$.

The delta $\mathrm{pH}$ of the topsoil, the difference of $\mathrm{pH}$ in $\mathrm{KCl}$ and $\mathrm{pH}$ in $\mathrm{H}_{2} \mathrm{O}\left(\mathrm{pHKCl}-\mathrm{pHH}_{2} \mathrm{O}\right)$, was significantly negative $(<-0.5)$. In the topsoil, the $\mathrm{KCl}$ depressed overall $\mathrm{pH}$ by approximately 1.0 unit (Fig. 4), suggesting that these soils have net negative charge and are cation exchangers (Uehara and Gillman, 1981). In the subsurface layer $(15-30 \mathrm{~cm}), 43 \%$ of the soil samples had a $\mathrm{pH}$ higher than the upper layers (data not shown).

The percentage of $\mathrm{Al}$ saturation of topsoil varied from $1.4 \%$ to $58.3 \%$. Fifteen percent of the samples contained more than 10\% Al saturation (Fig. 5). In extremely acidic soils with a $\mathrm{pH}$ less than 4.5 , the $\mathrm{Al}$ saturation was about $15 \%$. Assuming $10 \%$ of $\mathrm{Al}$ saturation as a critical level for most sensitive crops, several soils are likely to limit plant growth due to $\mathrm{Al}$ toxicity or $\mathrm{Ca}$ and $\mathrm{Mg}$ deficiency. The soils with probable acidity limitations were mainly found in high elevation regions.

The relationship between $\mathrm{pH}$ and extractable Al was best described by a nonlinear regression (Fig. 5). The coefficient of regression indicated that $68 \%$ of the variation of extractable Al could be predicted from soil $\mathrm{pH}$. Other studies report a similar, curvilinear-type relationship between extractable $\mathrm{Al}$ and $\mathrm{pH}$ (Kamprath, 1970; Coleman and Thomas, 1967).

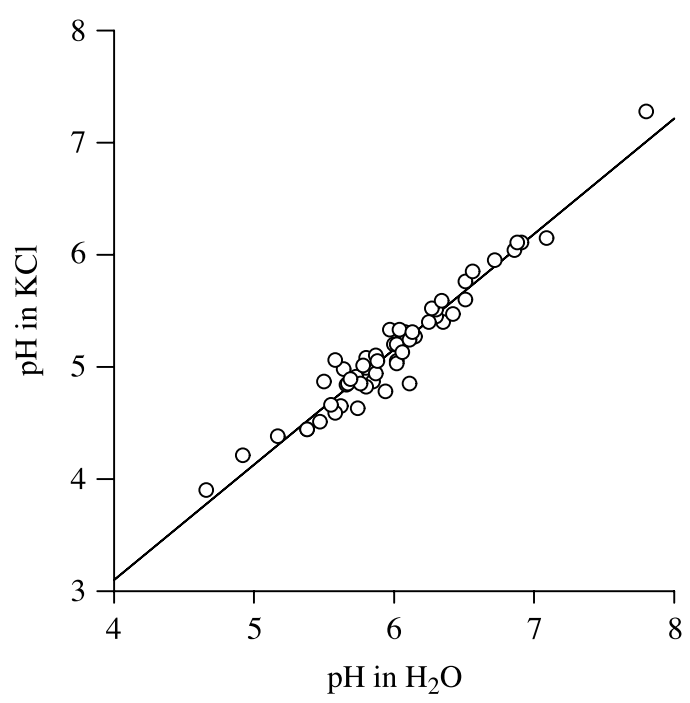

Fig. 4. The relationship between $\mathrm{pH}$ in $\mathrm{H}_{2} \mathrm{O}$ and in $\mathrm{KCl}$ of topsoil $(0-15 \mathrm{~cm})$. 


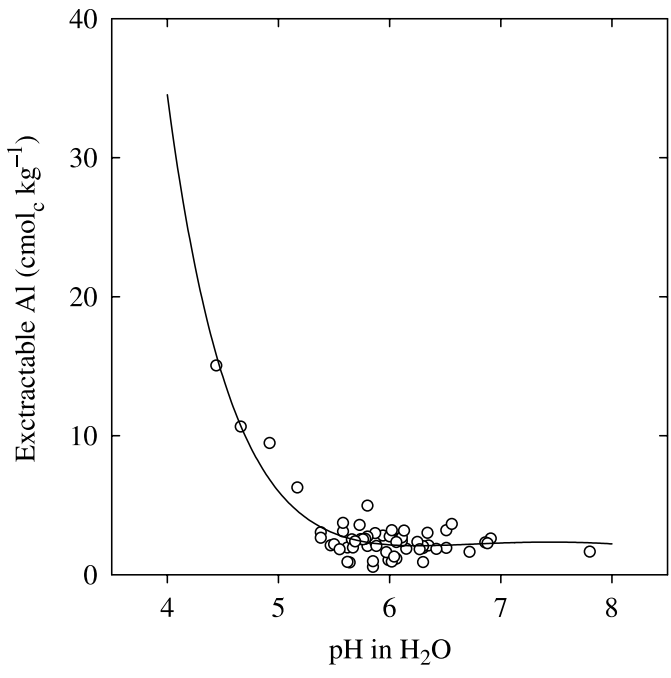

Fig. 5. The relationship between $\mathrm{KCl}$-extractable $\mathrm{Al}$ and soil $\mathrm{pH}$.

\section{Soil OM}

Soil OM ranged from $0.4 \%$ to $5.0 \%$. The median was $2.1 \%$, and about $47.5 \%$ of the samples had low to very low level. Roughly $46 \%$ of the samples were within the medium range $(2.0 \%-$ $4.0 \%$, Fig. 6). Only $5.5 \%$ of the samples had $4.0 \%$ or more OM. As expected, the amount of both total carbon and total nitrogen decreased with depth. In the surface layer, the range was from $0.39 \%$ to $5.7 \%$ organic matter, and the median was $2.1 \%$ organic matter. In the subsurface layer, the range was from $0.39 \%$ to $1.7 \%$, and the median was $1.4 \%$. Regression analysis of total carbon and total nitrogen indicated a positive relationship (Fig. 6). In the surface layer, $81 \%$ of the variation of total carbon can be attributed to the organic nitrogen. An analysis the relationship between clay content and OM showed no statistically significant correlation, possibly due to low clay content in these soils. Most of the samples have less than $20 \%$ clay.

\section{Cation Exchangeable Capacity}

The median ECEC was $5.0 \mathrm{cmol}_{\mathrm{c}} \mathrm{kg}^{-1}$ and ranged from 0.4 to $14.5 \mathrm{cmol}_{\mathrm{c}} \mathrm{kg}^{-1}$ (Fig. 7). Seventy-five percent of the samples had less than $7.5 \mathrm{cmol}_{\mathrm{c}} \mathrm{kg}^{-1}$, the minimum level for adequate exchange capacity according to the Instituto de Investigação Agrária de Moçambique (IIAM, formerly INIA) soil fertility capability classification system. Therefore, in general, these soils have between low and moderate fertility capability. Other investigators, however, have proposed $4 \mathrm{cmol}_{\mathrm{c}} \mathrm{kg}^{-1}$ as measured with unbuffered salt as the upper limit of low cation exchange capacity (Lopes and Cox, 1977).

In an attempt to evaluate the relationship between ECEC and soil OM, $\mathrm{pH}$ in $\mathrm{H}_{2} \mathrm{O}$, percent clay, percent silt, and extractable $\mathrm{Al}$, a stepwise multiple regression analysis was performed. The analysis indicated that $\mathrm{OM}$ and $\mathrm{pH}$ were statistically significantly correlated with ECEC at the 0.5 level of probability. Fifty percent of the observed variability of ECEC could be explained by OM content, and $64 \%$ of the variability could be explained by soil $\mathrm{pH}$ alone. The regression analysis did not identify clay or silt content as having a statistically significant contribution to the variability of ECEC. Table 2 shows the mean of soil properties according to FAO soil legend and by AEZ (Carta de Solos de Mozambique, 1996; Zonas Agroecologicas de Mozambique, 1980). The grouping by major soil type according FAO soil legend suggests inconsistent results when compared with the corresponding USDA Soil Taxonomy. The obvious reason seems to be the lack of sitespecific data in preparing the FAO Soil Map. Soil mapping for the FAO legend took place during the civil war when access to soil samples was impossible, consequently initial maps were based on inadequate satellite imagery in many areas rather than on field assessment with sample collection and analysis. The Rhodic Ferrasols, for example, should be somewhat analogous to Oxisols and Ultisols of the US Soil Taxonomy, yet the ECEC/100 g clay values were as high as 54.4 , which are values so high that they usually

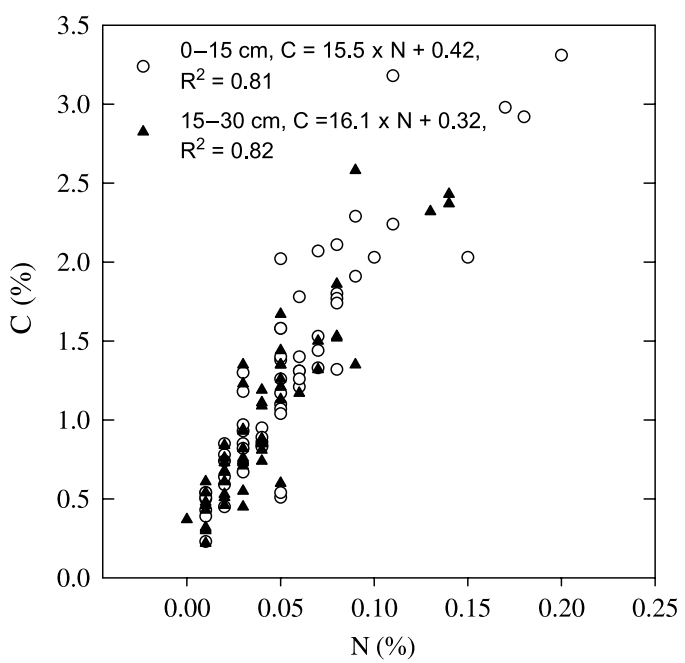

Fig. 6. The relationship between total $\mathrm{C}$ and total $\mathrm{N}$ of surface and subsurface layers. 
associated with soils with substantial 2:1 clays and thus were obviously misclassified.

These results point out the need for a thorough countrywide assessment and mapping of the soil resources based on laboratory soil data and modern mapping techniques such as remote sensing and soil sampling and analysis. A quantitative soil classification system such as the soil taxonomy would also contribute to improved soil resource assessment and ultimately to improved food security.

\section{Exchangeable Bases (Ca, $\mathrm{Mg}$, and $\mathrm{K}$ ) and Extractable P}

Surveys and preliminary estimates of critical levels of macronutrients in Mozambique soils
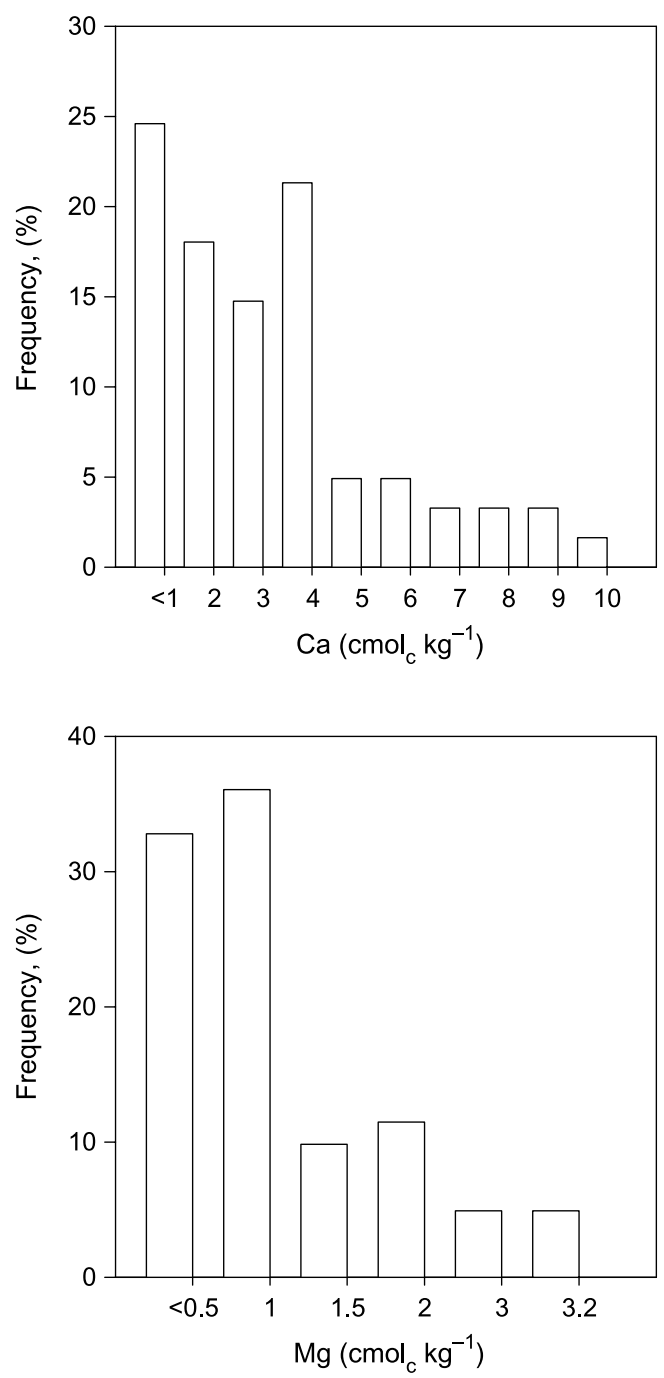

are scarce or nonexistent. The studies that exist deal largely with $\mathrm{N}$ and $\mathrm{P}$. Table 2 has been used for interpreting soil exchangeable bases (Eschwiler, 1986). Figure 7 shows the frequency distribution of exchangeable bases and extractable $\mathrm{P}$ of the surveyed soils.

The median of extractable Ca was $3.5 \mathrm{cmol}_{\mathrm{c}}$ $\mathrm{kg}^{-1}$, and the range was from 0.1 to $10.2 \mathrm{cmol}_{\mathrm{c}}$ $\mathrm{kg}^{-1}$. Approximately $21.3 \%$ of the samples were below the "adequate" level of $4.0 \mathrm{cmol}_{\mathrm{c}} \mathrm{kg}^{-1}$. Extractable $\mathrm{Mg}$ ranged from 0.1 to $3.2 \mathrm{cmol}_{\mathrm{c}}$ $\mathrm{kg}^{-1}$. The median was 0.7 . Assuming $0.5 \mathrm{cmol}_{\mathrm{c}}$ $\mathrm{kg}^{-1}$ as a lower limit of $\mathrm{Mg}$ adequate level, roughly $72 \%$ of the samples were within the "adequate" range. With regard to $\mathrm{K}$, the minimum level was 0.2 , and the maximum was 1.7 .
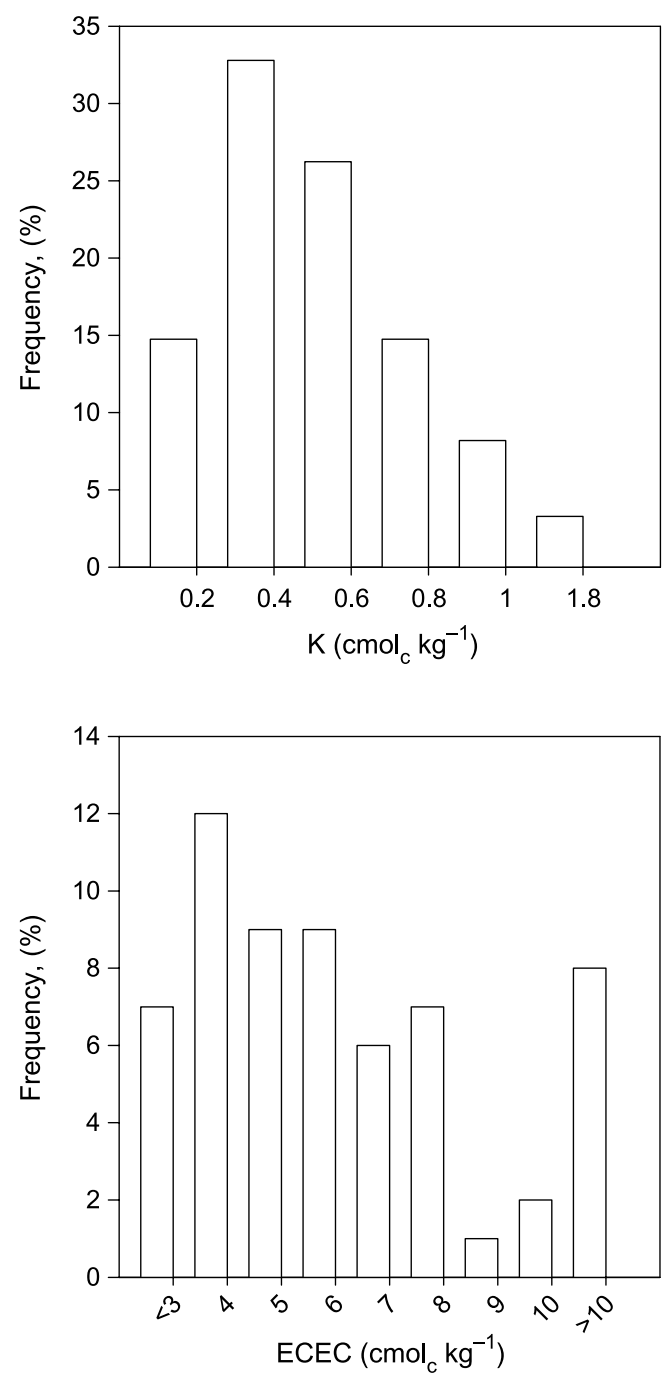

Fig. 7. Frequency distribution of soil cations in the topsoil. 
TABLE 2

Means of selected soil properties of topsoil $(0-15 \mathrm{~cm})$

\begin{tabular}{lccccc}
\hline FAO map units & $\mathrm{pH}$ & OM, $\%$ & Clay, $\%$ & ECEC $\left(\mathrm{cmol}_{\mathrm{c}} \mathrm{kg}^{-1}\right)$ & ECEC/100 g clay \\
\hline Rhodic Ferralsols & 5.7 & 2.5 & 19.8 & 5.2 & 54.4 \\
Lithosols & 5.5 & 1.8 & 15.2 & 4.0 & 26.6 \\
Ferric Luvisols & 6.3 & 2.3 & 21.3 & 6.4 & 37.0 \\
Lithosols-Luvisols & 6.3 & 1.9 & 21.4 & 7.0 & 39.2 \\
Orthic Ferralsols & 6.0 & 2.1 & 23.3 & 6.5 & 33.6 \\
\hline
\end{tabular}

The median was $0.41 \mathrm{cmol}_{\mathrm{c}} \mathrm{kg}^{-1}$. It seems that $\mathrm{K}$ is present in adequate levels. A frequency distribution of $\mathrm{Ca}, \mathrm{K}, \mathrm{Mg}$, and ECEC is shown in Fig. 7.

A comparison of soil nutrients by AEZ shows that the AEZ 10 in the central region is the most depleted of soil nutrients. The total $\mathrm{P}$ did not exceed $0.5 \mathrm{mg} \mathrm{kg}^{-1}$, and the levels of $\mathrm{Ca}$ and $\mathrm{Mg}$ were less than 2.3 and $0.7 \mathrm{cmol}_{\mathrm{c}}$ $\mathrm{kg}^{-1}$, respectively. In general, the AEZ 4, 7, and 8 contained low total $\mathrm{P}$ but moderate levels of $\mathrm{Ca}$ and $\mathrm{Mg}$ (Fig. 8, Table 1).

\section{Micronutrients ( $\mathrm{Zn}, \mathrm{Cu}, \mathrm{Mn}, \mathrm{Fe}$, and $\mathrm{B})$}

Micronutrients are not part of IIAM's soil routine analysis. Thus, the analysis given here provides one of the first estimates of micronutrient status (Fig. 9). There was no information or established critical levels of micronutrients. The comparisons of micronutrient analyses performed in this survey were based on the criteria proposed by Lindsay and Cox (1985) used in many countries in tropical regions (Table 4). The principle and methods used in extracting cations (Table 4) are somewhat comparable to Mehlich 3.

\section{Zinc}

Soil zinc ranged from 0.27 to $4.15 \mathrm{mg} \mathrm{kg}^{-1}$. The median was $0.96 \mathrm{mg} \mathrm{kg}^{-1}$. Roughly $10 \%$ of the samples had less than $0.5 \mathrm{mg} \mathrm{k}^{-1}$. Wear and Sommer (1948) considered $29 \mathrm{mg} \mathrm{kg}^{-1}$ extracted with $0.05 \mathrm{M} \mathrm{HCl}+0.05 \mathrm{M} \mathrm{H}_{2} \mathrm{SO}_{4}$ as a critical level. However, others have observed maize zinc-deficiency symptoms in a soil with between 0.2 and $0.5 \mathrm{mg} \mathrm{L}^{-1}$ obtained with $0.04 \mathrm{M}$ acetic acid extracting solution and from 0.5 to $0.9 \mathrm{mg}$ $\mathrm{kg}^{-1}$ with $0.1 \mathrm{M} \mathrm{HCl}$. A similar range of $\mathrm{Zn}$

TABLE 3

Soil property groupings, Instituto Nacional des Investigação Agronómica

\begin{tabular}{|c|c|c|c|c|c|}
\hline \multirow{2}{*}{ Soil properties } & \multicolumn{5}{|c|}{ Levels } \\
\hline & Very low & Low & Medium & High & Very high \\
\hline OM, \% & $<1.0$ & $1.0-2.0$ & $2.0-4.0$ & $>4$ & - \\
\hline $\mathrm{N}, \%$ & - & $0<0.1$ & $0.1-0.2$ & $>0.2$ & - \\
\hline $\mathrm{P}, \mathrm{mg} \mathrm{kg}^{-1}$ & - & $0-5.0$ & $5.0-10$ & $10-15$ & $>15$ \\
\hline \multicolumn{6}{|l|}{$\mathrm{K}, \mathrm{cmol}_{\mathrm{c}} \mathrm{kg}^{-1}$} \\
\hline Sandy soils, $(<10 \%$ clay $)$ & $0<0.05$ & $0.05-0.1$ & $0.1-0.4$ & $0.4-0.7$ & $>0.7$ \\
\hline Clay soils, (>40\% clay) & $0<0.2$ & $0.2-0.4$ & $0.4-1.2$ & $1.2-2.0$ & $>2.0$ \\
\hline Other soils & $0<0.1$ & $0.1-0.2$ & $0.2-0.4$ & $0.4-0.8$ & $>0.8$ \\
\hline \multicolumn{6}{|l|}{$\mathrm{Ca}, \mathrm{cmol}_{\mathrm{c}} \mathrm{kg}^{-1}$} \\
\hline Clay soils & $0<2.0$ & $2.0-5.0$ & $5.0-10.0$ & $10-20$ & $>20$ \\
\hline Other soils & $0<0.5$ & $0.5-2.0$ & $2.0-4.0$ & $4.0-6.0$ & $>6$ \\
\hline \multicolumn{6}{|l|}{$\mathrm{Mg}, \mathrm{cmol}_{\mathrm{c}} \mathrm{kg}^{-1}$} \\
\hline Clay soils & $0<0.2$ & $0.2-0.5$ & $0.5-1.0$ & $1.0-2.0$ & $>2.0$ \\
\hline Sandy soils & $0<0.3$ & $0.3-1.0$ & $1.0-3.0$ & $3.0-6.0$ & $>6.0$ \\
\hline $\mathrm{Na}, \mathrm{cmol}_{\mathrm{c}} \mathrm{kg}^{-1}$ & $0<0.1$ & $0.1-0.3$ & $0.3-0.7$ & $0.7-2.0$ & $>2.0$ \\
\hline $\mathrm{CEC}, \mathrm{pH} 7 \mathrm{cmol}_{\mathrm{c}} \mathrm{kg}^{-1}$ & $0<3$ & $3.0-7.5$ & $7.5-15$ & $15-30$ & $>30$ \\
\hline Base saturation, (\%) & $0<20$ & $20-40$ & $40-60$ & $60-80$ & $80-100$ \\
\hline \multicolumn{6}{|l|}{$\mathrm{pH}$ in $\mathrm{H}_{2} \mathrm{O}$} \\
\hline$<4.5$, Extremely acid & & & 6.1-6.5, Slightly acid & & \\
\hline 4.5-4.0, Very strongly acid & & & 6.6-7.3, Neutral & & \\
\hline $5.6-6.0$, Acid & & & 7.4-7.8, Slightly alkaline & & \\
\hline
\end{tabular}

Série Terra e Água do Instituto Nacional de Investigação Agronómica.

Comunicação No. 48.

CEC indicates cation exchange capacity. 
critical level was proposed by Lindsay and Cox (1985). It is generally believed that $\mathrm{pH}$ and OM are correlated with $\mathrm{Zn}$ availability. In our study, the amount of $\mathrm{Zn}$ did not significantly decrease with an increase of $O M$ or soil acidity, which suggests that other factors besides $\mathrm{OM}$ and $\mathrm{pH}$ control the availability of $\mathrm{Zn}$ in these soils. In general, Zn levels seem adequate, but AEZ 4 and 7 giving the lowest levels (Fig. 9).

\section{Copper}

The overall median of copper $(\mathrm{Cu})$ was 2.8 $\mathrm{mg} \mathrm{kg}-1$. The range was from 0.63 to $22 \mathrm{mg}$ $\mathrm{kg}^{-1}$. There were differences in $\mathrm{Cu}$ content among AEZ. Agroecological zone 10 seemed to contain substantially higher $\mathrm{Cu}$ content when
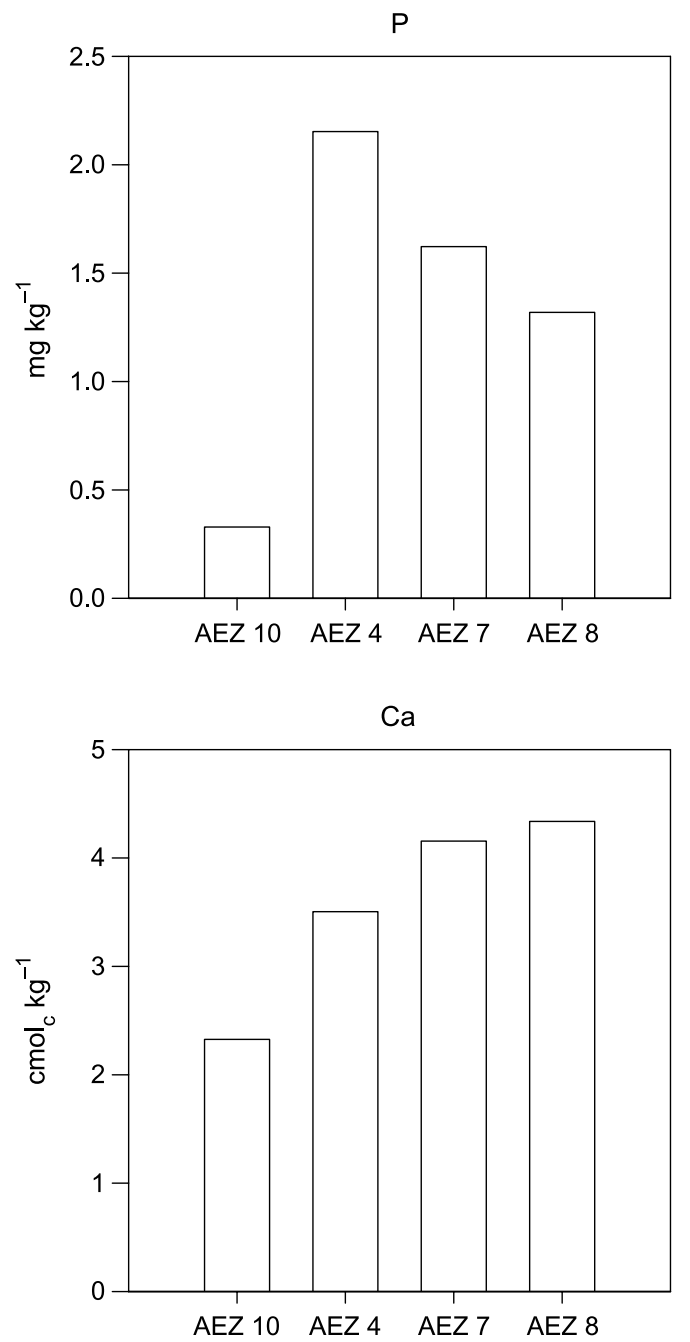

compared with AEZ 8 (Fig. 9). The reasons of such differences might be associated with the soil types. Several of the sampled sites in AEZ 10 were from lithic soils.

\section{Manganese}

Soils with low $\mathrm{pH}$ may lead to Mn toxicity in crops. Studies conducted elsewhere have indicated that $\mathrm{Ca}$ deficiency may be induced with high soil Mn. In Mozambique, there are no studies indicating $\mathrm{Mn}$ problem in acid soil. Soil measurement indicates slight variation of soil Mn content among AEZ. Agroecological zone 7 has a slightly higher Mn content (1235 $\mathrm{mg} \mathrm{kg}{ }^{-1}$ ) than other AEZ. An attempt to relate $\mathrm{Mn}$ content and soil $\mathrm{pH}$ shows no statistically
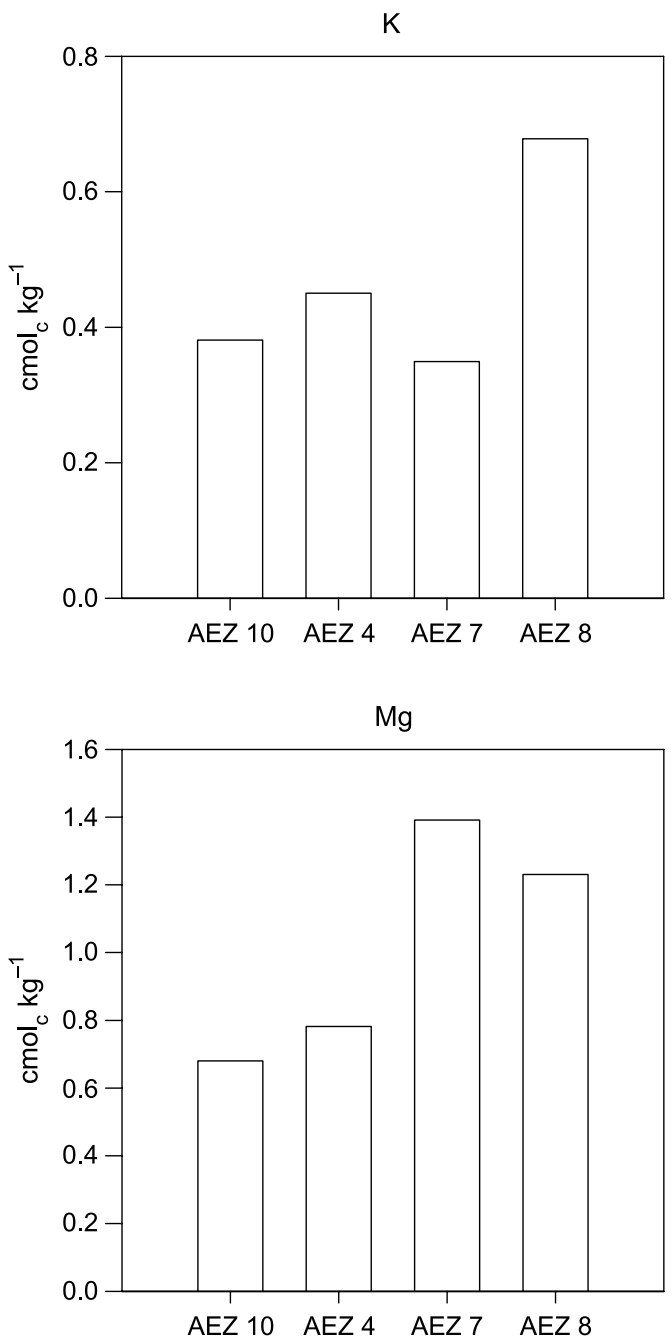

Fig. 8. Soil cations and ECEC of four AEZ of Mozambique. 

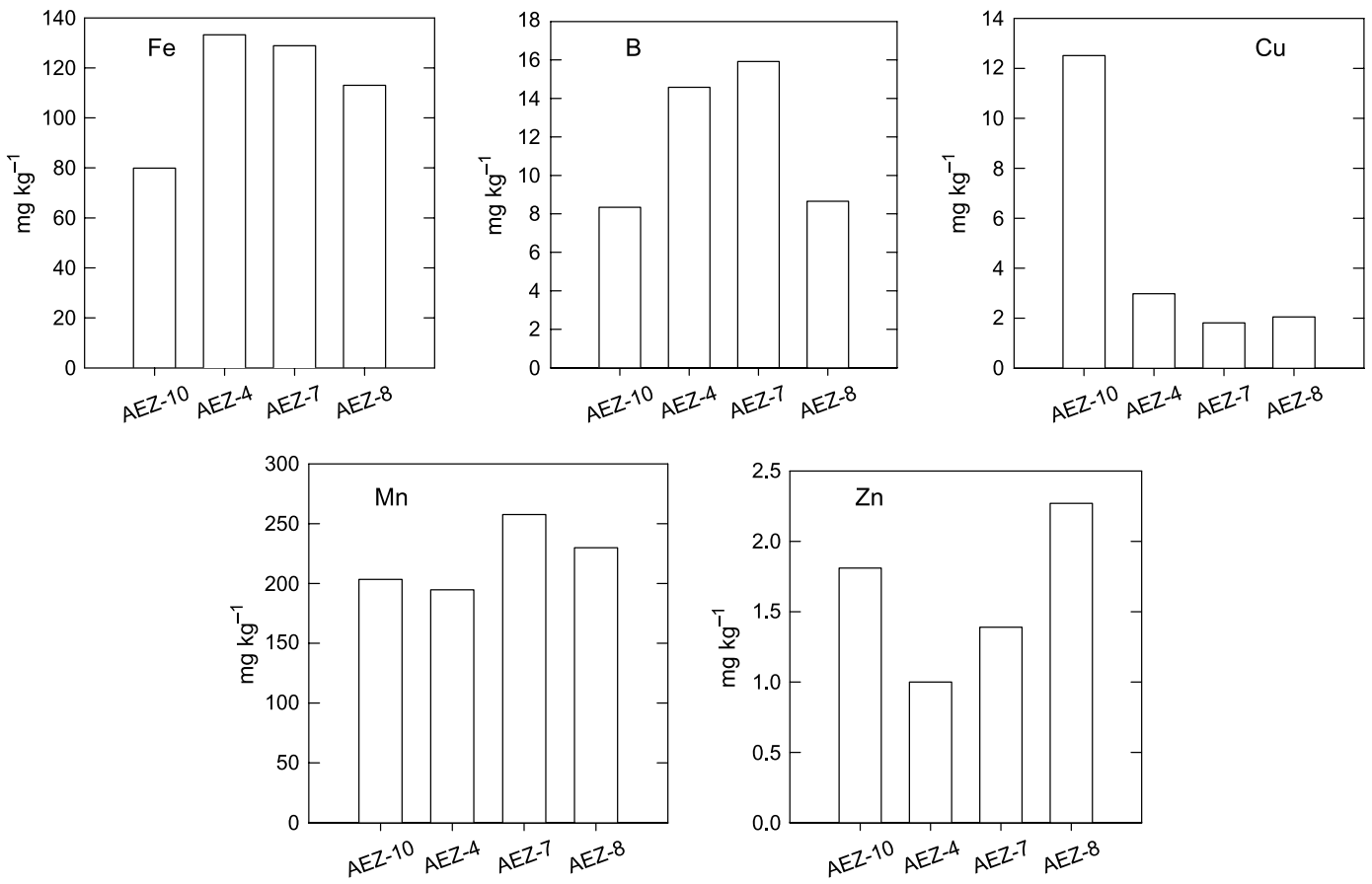

Fig. 9. Soil micronutrient contents of four AEZ of Mozambique.

significant correlation. The overall median of Mn content was $1015 \mathrm{mg} \mathrm{kg}^{-1}$, and the range was from 27 to $2470 \mathrm{mg} \mathrm{kg}^{-1}$.

\section{Iron}

The iron content varied significantly among soils. The S.D. was 50 . The range was from 38.4 to $279 \mathrm{mg} \mathrm{kg}^{-1}$. The median was $116 \mathrm{mg} \mathrm{kg}^{-1}$. There are presently no studies that have been conducted in Mozambique that relate crop performance and $\mathrm{Fe}$ availability. Lindsay and Cox (1985) suggest 0.4 to $10 \mathrm{mg} \mathrm{kg}^{-1}$ as a critical level. Assuming $10 \mathrm{mg} \mathrm{kg}^{-1}$ as lower limit of critical level, all samples have sufficient Fe.

\section{Boron}

The median level of B in surveyed soils was $16.0 \mathrm{mg} \mathrm{kg}{ }^{-1}$. The range was from 1.81 to 35.5

TABLE 4

Summary of soil extracting solutions, shaking times, and ranges of critical levels for micronutrients used in many countries in tropical regions

\begin{tabular}{|c|c|c|c|c|}
\hline Micronutrient & Extracting solutions & $\begin{array}{c}\text { Soil/ } \\
\text { solution } \\
\text { ratio }\end{array}$ & $\begin{array}{l}\text { Time of } \\
\text { shaking }\end{array}$ & $\begin{array}{c}\text { Range of } \\
\text { critical level } \\
\left(\mathrm{mg} \mathrm{kg}^{-1}\right)\end{array}$ \\
\hline Iron & $\begin{array}{c}\text { DTPA, } \mathrm{NH}_{4} \mathrm{OAC}, \mathrm{HCl}, \mathrm{NaHCO}_{3}, \mathrm{EDTA}, \mathrm{NH}_{4} \mathrm{~F} \\
\text { and } \mathrm{Na} \text { Citrate }\end{array}$ & $1: 2$ and $1: 40$ & $\begin{array}{l}10 \mathrm{~min} \text { to } \\
2 \mathrm{~h}\end{array}$ & $0.4-10$ \\
\hline Manganese & $\begin{array}{c}\text { DTPA, } \mathrm{NH}_{4} \mathrm{OAC}, \mathrm{HCl}, \mathrm{NaHCO}_{3} \text {, EDTA, } \mathrm{NH}_{4} \mathrm{~F}, \mathrm{H}_{2} \mathrm{SO}_{4} \text {, } \\
\text { and } \mathrm{Na} \text { Citrate }\end{array}$ & $1: 2$ and $1: 20$ & $\begin{array}{l}5 \min \text { to } \\
2 \mathrm{~h}\end{array}$ & $1-20$ \\
\hline Zinc & $\begin{array}{c}\text { DTPA, } \mathrm{NH}_{4} \mathrm{OAC}, \mathrm{HCl}, \mathrm{NaHCO}_{3}, \text { EDTA, } \mathrm{NH}_{4} \mathrm{~F}, \mathrm{KCl} \text {, } \\
\text { and } \mathrm{H}_{2} \mathrm{SO}_{4}\end{array}$ & $1: 2$ and $1: 20$ & $\begin{array}{l}5 \mathrm{~min} \text { to } \\
3 \mathrm{~h}\end{array}$ & $0.5-10$ \\
\hline Copper & DTPA, $\mathrm{NH}_{4} \mathrm{OAC}, \mathrm{HCl}, \mathrm{NaHCO}_{3}$, EDTA, and $\mathrm{NH}_{4} \mathrm{~F}$. & $1: 2$ and $1: 20$ & $\begin{array}{l}5 \mathrm{~min} \\
2 \mathrm{~h}\end{array}$ & $0.2-10$ \\
\hline Boron & $\mathrm{Ca}\left(\mathrm{H}_{2} \mathrm{PO}_{4}\right)_{2} \cdot \mathrm{H}_{2} \mathrm{O}, \mathrm{H}_{2} \mathrm{SO}_{4}, \mathrm{NH}_{4} \mathrm{~F}$, and $\mathrm{HCl}$ & $1: 1$ and $1: 2$ & 5 min to & $0.2-2$ \\
\hline
\end{tabular}

Source: Lindsay and Cox (1985).

DTPA indicates diethylenetriamine pentaacetic acid. 
$\mathrm{mg} \mathrm{kg}^{-1}$. Boron deficiency might occur in a soil with a high percentage of OM or in soil of light texture. Neither case was found at sample sites, which suggests that B availability in these soils might not be a problem.

\section{Phosphorous Sorption}

The $\mathrm{P}$ sorption curves indicate that these soils have low (10-100 mg P per kilogram of soil) to medium (100-500 $\mathrm{mg}$ P per kilogram of soil) sorption capacity according to Juo and Fox's (1977) grouping (Fig. 10). The results show little displacement of the curves to the right at $0 \mathrm{P}$ added, which indicates that these soils have low P. The amount needed to attain $0.2 \mu \mathrm{g} \mathrm{mL}^{-1}$ in the equilibrated solution, a level considered adequate for normal plant growth (Fox and Kamprath, 1970) ranged from approximately 200 to $400 \mathrm{mg} \mathrm{kg}^{-1}$. The Orthic Ferrasols (Fr) and Ferric Luvisols (Lf) sorbed the most $\mathrm{P}$ probably as a result of the moderate to high clay percentage, 28.9 and 15.5 , respectively, and their highly weathered condition.

\section{Comparison of Soil Properties Among Four AEZ}

Agroecological zones represent important regions for food production and economic development. According to the IIAM (formerly INIA), Mozambique has 10 AEZ. A comparison among the zones shows some differences and similarities. Major differences exist in crop and cropping systems among the four AEZs selected for this study. Cotton, cassava, and groundnut are the major crops in AEZ 7 and 8 in the northern provinces of Nampula and Cabo-Delgado, whereas in the central Mozambique (AEZs 4 and 10), maize and millet are traditionally cultivated by small-scale farmers.

Statistical analysis of soil macronutrients $(\mathrm{Ca}$, $\mathrm{Mg}, \mathrm{K}$, and $\mathrm{Na}$ ) and micronutrients $(\mathrm{Zn}, \mathrm{Mn}$, and $\mathrm{Fe}$ ) indicated no statistical differences among the four AEZ. There was slight variation in soil $\mathrm{pH}$ and extractable Al.

Agroecological zone 8, situated in northern Mozambique, seems to have relatively better soil fertility capability compared with other regions. The ECEC, clay percentage, organic carbon, and $\mathrm{pH}$ in this region were generally higher than in the other regions. Extractable Ca ranged from 0.9 to $9.1 \mathrm{cmol}_{\mathrm{c}} \mathrm{kg}^{-1}$, and the median was $3.2 \mathrm{cmol}_{\mathrm{c}} \mathrm{kg}^{-1}$. Soil $\mathrm{Mg}$ ranged from 0.3 to 3.2 $\mathrm{cmol}_{\mathrm{c}} \mathrm{kg}^{-1}$. The median was $0.6 \mathrm{cmol}_{\mathrm{c}} \mathrm{kg}^{-1}$. Assuming $1.0 \mathrm{cmol}_{\mathrm{c}} \mathrm{kg}^{-1}$ is a medium level (according IIAM's soil fertility capability classification), 7 of 13 samples in this region are below the medium category. Potassium level was within the adequate range. The range was from 0.1 to $1.7 \mathrm{cmol}_{\mathrm{c}} \mathrm{kg}^{-1}$, and the median was $0.4 \mathrm{cmol}_{\mathrm{c}} \mathrm{kg}^{-1}$.

Agroecological zone 10, in Manica province, was characterized by relatively more acidic conditions, together with low ECEC, but slightly higher OM than the AEZ 7 and 8 . Differences were also observed with regard to the $\mathrm{P}$ sorption capacity. Generally, AEZ 4 revealed higher $\mathrm{P}$ sorption capacity. The obvious reason seems to be the high reactivity

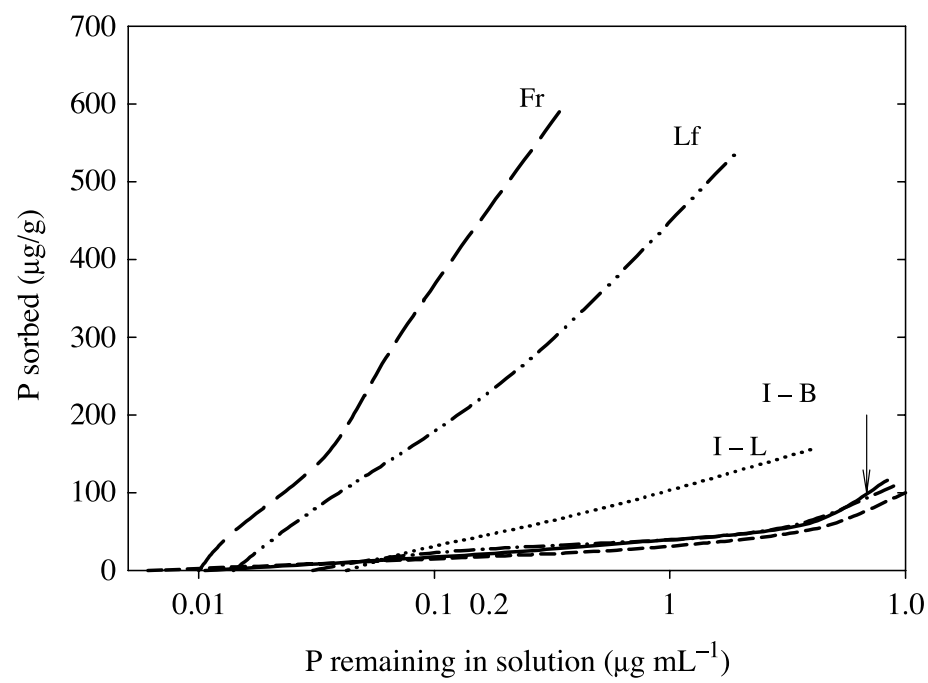

Fig. 10. Phosphorus sorption curves of selected topsoils of four agroecological zones of Mozambique. 
of the soils in this region. The comparison of Xray diffractograms indicates high reflection intensities of these soils in the regions 2.3 to 2.5, 4.1 to 4.9 , and 4.7 to $4.85 \AA$ (Fig. 3), which corresponds to hydroxides, oxyhydroxides, and oxides of Fe and $\mathrm{Al}$. Thus, this region seems to have higher $\mathrm{Fe}$ and $\mathrm{Al}$ content than region 8.

\section{Predicting Fertilizer Needs for Maize with NuMaSS and PDSS}

In agriculture, decision aids have proven to be very useful tools for predicting crop yield, plant growth, or fertilizer needs. In this study, soil nutrient requirement was predicted with computer software (NuMaSS and PDSS). The NuMaSS and PDSS are innovative approaches of predicting nitrogen, $\mathrm{P}$, and potassium needs. The $\mathrm{N}$ module is based on Stanford equation that takes into account crop removal and soil site-specific information (soil nutrient condition, crop residual, and manure application). The estimation of $\mathrm{P}$ needs takes into account soil reactivity toward fertilizer $\mathrm{P}$ added, the crop requirement, placement factors, and the application method.

The prediction of $\mathrm{N}$ and $\mathrm{P}$ requirements indicates clearly that most of the soils in Mozambique are deficient. The range of $\mathrm{N}$ fertilization needs for a target yield of $4000 \mathrm{~kg}$ $\mathrm{ha}^{-1}$ for maize ranged from 1.46 to $250 \mathrm{~kg} \mathrm{ha}^{-1}$ in more depleted areas. The median was $164 \mathrm{~kg}$ $\mathrm{N} \mathrm{ha}^{-1}$, which is substantially high for Mozambican farmers' with limited resources. The $\mathrm{P}$ needs ranged from 3.8 to $13.9 \mathrm{~kg} \mathrm{ha}^{-1}$. The median is $13.1 \mathrm{~kg} \mathrm{ha}^{-1}$. The results of the prediction of crop nutrient requirements show no consistent difference of fertilizer needs among AEZ. However, the $\mathrm{N}$ and $\mathrm{P}$ needs seem to be correlated with the clay content.

\section{CONCLUSIONS}

Several previous field surveys have indicated that soil fertility is a fundamental problem to food production in Mozambique. However, there are very few studies that provide the necessary quantitative data indicating which nutrients are deficient and where, and which would enable site-specific soil nutrient management. Our study suggests that most of the soils have low ECEC, which is probably because of the kaolinitic mineralogy, which was identified in many of the surveyed soils. Soil acidity in the high rainfall, high elevation region is likely to limit crop production. In those areas with low $\mathrm{pH}$, soil $\mathrm{P}$ was much lower, probably due to the high $\mathrm{P}$ sorption capacity. X-ray diffractograms indicate kaolinite and oxides and hydroxides of $\mathrm{Fe}$ and $\mathrm{Al}$ as the predominant clay minerals of these soils. Such materials strongly sorb P, which is of significant importance in controlling $\mathrm{P}$ availability. A comparison of soil properties belonging to different FAO categories shows little differences; probably, this owes to insufficient and inadequate field surveys and data collection during the civil war. The difficulties found in the FAO grouping point to a need for a modern, systematic survey of the soil resources of Mozambique.

\section{REFERENCES}

Brindley, G. W., and G. Brown. 1980. Crystal structures of clay minerals and their X-ray identification. Mineralogical society, Pennsylvania.

Coleman, N. T., and G. W. Thomas. 1967. The basic chemistry of soil acidity. In: Soil Acidity and Liming. Agronomy 12:1-41. R. W. Pearson and F. Adams (eds.). Am. Soc. of Agron., Madison, WI.

Eschwiler, J. A. 1986. O potencial agrário da área do projecto 400,000 ha na provincia de Cabo Delgado (Parte Sul). Umpublished document, INIA, Maputo, Mozambique.

Carta de Solos de Mozambique. Legenda da FAO, IIAM (1996).

Folmer, E. C. R., P. M. H. Guerts, and J. R. Francisco. 1998. Assessment of soil fertility depletion in Mozambique. Agriculture, Ecosystem and Environment 71:159-169.

Fox, R. L., and E. J. Kamprath. 1970. Phosphate sorption isotherms for evaluating the phosphate requirements of soils. Soil Sci. Soc. Am. Proc. 34:902-907.

Gee, G. W., and J. W. Bauder. 1986. Particle Size Analysis. In: Methods of Soil Analysis, Part 1. A. Klute (ed.). 2nd Ed., Vol. 9. Am. Soc. Agron., Madison, WI, pp. 383-411.

Juo, A. S. R., and R. L. Fox. 1977. Phosphate sorption characteristics of some bench-mark soils of West Africa. Soil Sci. 124:370-376.

Kamprath, E. J. 1970. Exchangeable aluminum as a criterion for liming leached mineral soils. Soil Sci. Soc. Am. J. 34:252-254.

Lindsay, W. L., and F. R. Cox. 1985. Micronutrients in Tropical Food Crop Production. In: Developments in Plant and Soil Sciences. P. L. G. E. Vlek (ed.). Vol. 14. Springer.

Lopes, A. S., and F. R. Cox. 1977. A survey of the fertility status of surface soils under "Cerrado" vegetation in Brazil. Soil Sci. Soc. Am. J. 41:742-747.

Moore, D. M., R. C. Reynolds, and J. Reynolds. 1989. X-Ray diffraction and identification and analysis of clay minerals. Oxford University Press, New York, NY.

Olsen, S. R., and L. E. Sommers. 1982. Phosphorus. 
In: Methods of soil analysis, Part. 2. A. L. Page et al. (ed.). 2nd ed. Agronomy Monogr. 9. ASA and SSSA, Madison, WI, pp. 403-410.

Rajan, S. S. S., and R. F. Fox. 1972. Phosphate adsorption by soils I. Influence of time and ionic environment on phosphate adsorption. Commun. Soil Sci. Plant Anal. 3:493-504.

Ribeiro, L. 1976. Introdução ao estudo da mineralogia dos solos de Ibitiara, BA, in Anáis do décimo quinto congresso Sociedade Brasileiro de Ciência do solo. ociedade Brasileira de Ciencia do Solo, Campinas, SP, Brazil, pp. 423-427.

SAS Institute, 1997. SAS User's Guide: Statistics. Release 6.12, Cary, NC.
Uehara, G., and G. P. Gillman. 1981. The mineralogy, chemistry, and physics of tropicalsoils with variable charge clays. Westview Press, CO.

Wear, J. L., and A. L. Sommer. 1948. Acid extractable zinc of soils in relation to the occurence of zinc deficiency symptoms of corn: a method of analysis. Soil Sci. Soc. Amer. Proc. 12:143-144.

Whittig, L. D. 1959. Characteristics and genesis of a Solodized-Solonetz of California. Soil Sci. Soc. Am. J. 64:765-773.

Zonas Agro-ecologicas de Moçambique. Instituto de Investigação Agronómica de Moçambique (INIA), 1980. 